\title{
Socio-Economic Strategy of Sustainability and Post-Mining Land Use in South Sumatra
}

\author{
Rizkia Ayu Lestari ${ }^{1}$, Mahawan Karuniasa ${ }^{1}$, Tri Edhi Budhi Soesilo ${ }^{1}$, and Lana Saria ${ }^{2}$ \\ ${ }^{1}$ School of Environmental Studies, Universitas Indonesia. Adress: Environmental School Post \\ Graduate Building, Universitas Indonesia Salemba Campus J1. Salemba Raya No.4 Jakarta Pusat \\ ${ }^{2}$ General Directorate of Mineral and Coal, Ministry of Energy and Mineral Resources, Jakarta
}

\begin{abstract}
This open-pit mining activity has a very helpful environmental potential, soil chemistry, erosion and sedimentation. Change in land use from mining actively after mining requires land and energy closure to ensure that the land is safe for and returned. In accordance with the local spatial pattern in Muara Enim, South Sumatra, the transfer of post-mining land after the dismissal of mining operations will be used as a conservation area managed by the mining community. The concept is an environmental addressing plan to determine the sustainability of various aspects of community life, including local sustainability, food environment, awareness, biodiversity, and sustainability. This study aims to ensure community sustainability after mining operations. The methodology that is an interview with Experts. The results of this research indicate that community empowerment in mining area can use one of the community's natural resource management strategies to ensure social sustainability with land use as agroforestry and integrated agricultural industries.
\end{abstract}

\section{Introduction}

Along with the depletion of materials stored in the area, and different activities, postmining land can provide benefits to the wheel of the economy in the area. This is what encourages us to find out more about spatial planning for the development of post-mining areas for use. Type of land use, land use based on circumstances and socio-economic conditions, such as the constituent components of plants used and their benefits to the community. Several types of plants can be used in post-mining area to be used by local people [1].

Sustainability is one of the principles used to solve problems and see the sustainability of post-coal mining land in Tanjung Enim. In the principle of sustainability there are factors that are interconnected between social, economic and environmental. Study of environmental sustainability based on recovery in refugee areas. The recovery of the postmining ecosystem has also become one of the benefits that can be taken to support the ongoing life of the community around the mine area after additional materials have been excavated and mining operations are declared stopped. Assessment of the recovery of ecosystems also uses the principle of interaction. A population will not produce in the form of a living system without interaction and society and social environment. 
Agroforestry is a form of resource management that combines forest management with commodity cultivation (short-term crops). Agroforestry is also a landscape object that is used in activities for agroforestry patterns[2]. Simply stated, agroforestry means planting trees on agricultural land, which is managed by the community. Agroforestry not only focuses on technical and biophysical issues, but also social, economic, and cultural issues that change over time.

The company has planted commodity crops that have economic value such as eucalyptus plants, fragrant betel, mango, guava, rambutan, longan, tomatoes, and sweet potatoes. Agroforestry planning is directed towards agrosilvopastura which includes forestry, agriculture and livestock. Stakeholder preferences for commodities that can be developed further indicate that land suitability is the most criteria for post-mining land use [3]. Development of crop commodities developed in agroforestry areas also requires consideration of market availability that will absorb various products produced from agroforestry land.

In this paper, it focuses on, (1) identifying problems for community sustainability around the mine to survive after mining operations are completed based on socio-economic aspects through agroforestry, (2) analyzing community sustainability around the mine based on socio-economic aspects of agroforestry activities.

\section{Materials and Methods}

The calculation of agroforestry valances carried out refers to the Minister of Environment Regulation No. 15 of 2012 concerning the Guide to Forest Ecosystem Valuation and uses the benefit transfer method in an area of 15.421 ha. The calculation results are obtained based on the calculations made by [3] regarding the total economic value of SDALH about the valuation of the former integrated surface mining landscape. the price obtained is the result of recalculation of commodity prices with a real time price survey and estimated prices calculated using the updated benefit transfer method with reference to the inflation report issued by Bank Indonesia in April 2018, with an inflation rate of $3.41 \%$.

To target people who are willing to work with companies to do agroforestry, a detailed social mapping is needed to portray people who have expertise in agriculture and animal husbandry and are willing to work.

\section{Results and Discussions}

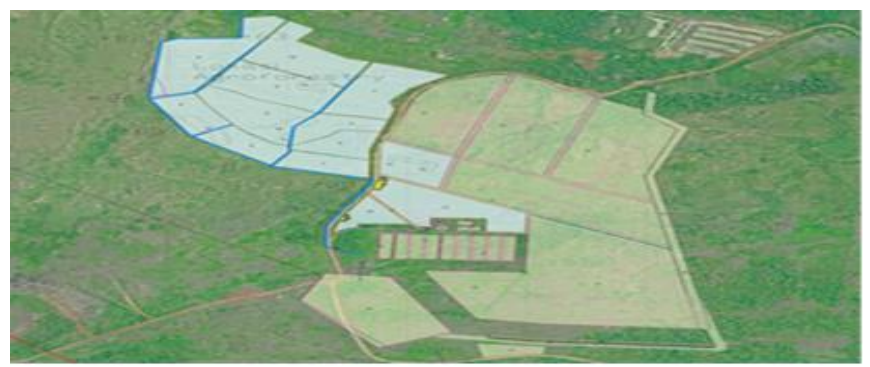

Agroforestry locations are generally in the form of undulating hills, and are determined by ultisol soils with $\mathrm{pH}$ activating, so that the soil has a slow air characteristic. Based on a field survey, and a post-mining plan map of West Banko, the reclamation area uses the blocks used for economic, social and cultural purposes. 
The utilization of resources in the reclamation land must pay attention to the potential, carrying capacity, and diversity of wild plants and animals. The utilization block consists of areas of ex-excavation that have been buried, original land that is not used for mining activities (buffer zone). Referring to the Muara Enim Regency spatial plan regarding the planned pattern of post-mining area space plans when they are fully closed is functioned as a cultivation and tahura area.

Spatial planning to support agrosilvopastura is carried out in certain blocks following the existing conditions planned by the company. Some considerations in the planning map that have been made are divided into special blocks for agroforestry, silviculture and pasture. The pastura area consists of one community cow enclosure with a capacity of 300 heads and one 240 ettawa goat cage, one catfish pond, with supporting facilities for processing goat and cow dung which are used as organic fertilizer and bio gas. In addition it is also planned to build a reservoir for irrigation, livestock drinking sources, and agroindustrial water sources. To support the availability of animal feed, there are four grasslands that can accommodate 800 animals. Agrosilvopastura area will also be used as a natural tourist area with a plan for the construction of a deer enclosure covering $16.605 \mathrm{~m}^{2}$.

The agroforestry block consists of fruit and vegetable crops as in area 1 planted with pineapple, matoa, guava, guava, and cavendis bananas. In area 2, it is planted with eggplant, tomatoes, calsim, purple eggplant, kale, green spinach, red ginger, soybeans, peanuts, chili and lettuce. Whereas silvicultural blocks are planted with woody plants that have a market and economic value including eucalyptus, gaharu, merbau, tembesi, sereh wangi, sengon and jabon plants.

Agroforestry land is planned to be carried out on an area of 15.421 ha which includes three IUPs in mining units in the UPTE area, namely Banko Barat IUP, Air Laya IUP, and Muara Tiga Besar IUP.Development of crop commodities developed in agroforestry areas also requires consideration of market availability that will absorb various products produced from agroforestry land. Some commodities that already have mature planning and markets are then calculated the results obtained for each harvest period. Calculations made on the value of environmental services are carried out using the benefit transfer method which refers to the results of research conducted by Kodir in PTBA Tanjung Enim after mining. The benefit method referred to uses the assumption of estimated value in accordance with previous research and uses Minister of Environment Regulation No. 15 of 2012 concerning Guide to Economic Valuation of Forest Ecosystems.

Table 1. Results of agroforestry businesses of each harvest period

\begin{tabular}{|c|c|c|c|}
\hline Product & $\begin{array}{c}\text { Commodities } \\
\text { (Rupiah) }\end{array}$ & $\begin{array}{c}\text { Harvest } \\
\text { Operating costs }\end{array}$ & Net profits \\
\hline Cow & 1.300 .000 .000 & 840.887 .000 & 459.113 .000 \\
\hline Parrot fish & 316.800 .000 & 155.490 .000 & 161.310 .000 \\
\hline Jabon tree & 2.786 .349 .000 & - & 2.786 .349 .000 \\
\hline Eucalyptus & 1.795 .690 .000 & 217.500 .000 & 1.578 .190 .000 \\
\hline \multicolumn{3}{|c}{} & 4.984 .962 .000 \\
\hline
\end{tabular}

By doing recalculation in accordance with the interim planning that [3] has conducted, agroforestry land will develop Jabon crops in an area of \pm 5454 ha. Jabon plant is a plant with a planting age of seven years which is predicted to have an average height of $12.5 \mathrm{~m}$ and a diameter of $25 \mathrm{~cm}$ [4]. Assuming the yield of Jabon planting after the seventh year can be harvested every year, 5454 ha of land is divided into seven blocks with an area of 
779 ha each. Planting seeds with a $4 \times 4$ spacing will require 625 seedlings per hectare and 486.875 trees/block. Of the 486.875 trees, $4038 \mathrm{~m} 3$ of wood is ready for sale. The current selling value of Jabon wood is around Rp. $690.000 .00 / \mathrm{m} 3$ to obtain sales of around 2.786.349.000.00 per year.

One of the commodities that has been cultivated and processed and involves the community is the cultivation of cassava and its oil processing for sale by utilizing the kayuputih refinery house. Kayuputih is a fast growing plant and has a high adaptability as well as one of the plants that can grow well in the PTBA post-mining area, with a total planting area reaching 1.700 ha. Based on research conducted by [3] the selling price of kayuputih oil processed by PTBA ranges from Rp. 190.000.00/ kg. Assuming a planting area of 1700 ha is planted entirely with kayuputih trees with a $4 \times 4$ planting distance and the number of trees is 625 / ha, it takes 1.062 .500 seeds of cassava seeds. 1.062 .500 kayuputih trees are assumed to be able to produce $1.062 .000 \mathrm{~kg}$ of leaves. Through the distillation process with a yield of $0.89 \%$ [4], it was obtained $9.451 .80 \mathrm{~kg}$ of kayuputih oil which was worth Rp. 1.795.690.000.00.

Pastura activities that will be developed in agroforestry fields focus on cattle farming. One of the goals of developing cattle breeding is the large number of domesticated cattle that are released in revegetation areas that disturb and become revegetation pests, so an idea was made to collaborate with the community to initiate cattle breeding. The area planned for the farm area and will be filled with beef cattle, covering an area of 782 ha. At the initial stage, 100 cows will be developed with a fattening period for six months. Cattle farming in agroforestry areas is expected to provide animal protein needs for the area around the estuary enim. The maintenance of beef cattle is done by grazing in the pasture land. Therefore, it is necessary to plant grass species that can adapt to the acidic conditions of ultisol soil. One type of grass that is tolerant to acid soils is razi grass (Brachiaria decumbens), carpet grass (Axonophus compressus) Bengal grass (Panicum maximum), king grass (Penissetum purpuroides), bahia grass (Paspalum notatum) and elephant grass (Penissetum purpureum).

The result of developing 100 beef cattle with the assumption that the cow will be harvested per period, with a length of one fattening period for six months with 50 cows with an average weight of about $400 \mathrm{~kg}$ will be obtained as much as $50 \%$ cow carcass [5] $200 \mathrm{~kg}$ of beef is ready for sale per cow. The price of beef in 2018 ranges from Rp $130.000 .00 / \mathrm{kg}$, from the calculation will be obtained 10 tons of beef with a selling value of 1.300.000.000.00 per period and 2.600.000.000.00 per year.

Development of floating net cages for tilapia cultivation in the area of 112.49 ha with a cage size capacity of $4 \mathrm{~m} \times 4 \mathrm{~m} \times 2 \mathrm{~m}$ which can accommodate 1000 fish, 32 floating cages can be built. With a harvest period of four months, harvesting can be done in one year with an estimated yield of $330 \mathrm{~kg} /$ hole [3]. The price of tilapia in South Sumatra in 2018 ranges from Rp. $30.000 .00 / \mathrm{kg}$. Referring to the current price, the sales proceeds are around Rp. 316.800.000.00 in one harvest period and 950.400.000.00 per year. All recalculation is carried out without including maintenance, feed and wage costs for workers due to limitations in this study.

Calculation using benefit transfer refers to the research conducted by[3]) which examines the economic value of environmental natural resources in Bukit Asam in 2015 by utilizing post-mining land into productive land covering 15.421 ha with a value of $\mathrm{Rp}$ 2.598.985.00/ha/year. With the post-mining land use plan, a value of Rp. 40.078.947.685.00 will be obtained.The results of the social mapping carried out obtained the results of the classification of types of work in the area of the mine circumference as follows. 
Table 2. Type of Mine Circle Community Work

\begin{tabular}{|c|c|c|c|}
\hline No & Jobs & Year 2015 (\%) & Year 2016 (\%) \\
\hline 1 & Employee & 40.31 & 39.33 \\
\hline 2 & Laborer & 29.38 & 20.01 \\
\hline & $\begin{array}{c}\text { Civil Servant/Indonesian } \\
\text { National Armed } \\
\text { Forces/Indonesian National } \\
\text { police }\end{array}$ & 18.6 & 17.9 \\
\hline 4 & Farmer & 10.08 & 10.12 \\
\hline 5 & Trader & 11.63 & 12.22 \\
\hline
\end{tabular}

The dominant type of jobs owned by the community around the mine in 2016 was as a company employee of 39.33 and a laborer of 20.01. This will have a significant impact if mining operations are completed and terminated, which will cause many communities to circle the mine that lost their livelihoods and sources of income. To maintain the ongoing economic activities of the community around the mine area, efforts are needed to build sustainable environmental development and mining control programs that will make the most of post-mining land into productive land that will absorb labor and generate economic benefits. Taking into account the mining circle community was an agrarian community, an agroforestry program was launched which gave the community the opportunity to circle the mine to participate.

Community involvement in environmental and socio-economic sustainability activities was assessed based on community participation in environmental conservation activities through a revegetation program in PTBA's reclamation activities on its post-mining land. Socio-economic sustainability through agroforestry programs is designed through the establishment of production houses. Production houses are designed to process agroforestry commodities or only sell directly agroforestry products. who will gather into cooperatives. The formation of a container in the form of cooperatives aims to provide capital, savings and loans, conduct trainings and connect the community with the market.

\section{Conclusion}

The land and environmental services that have been carried out are expected to contribute to the interests of the communities around the mine to support the sustainability of their economic and social functions. To facilitate this need, PTBA started activities that combined economic, social and environmental aspects with agroforestry activities. In agroforestry activities, local plants are developed with economic and market value. The type of business developed in agroforestry takes into account the habits of communities around the mine who develop woody plants such as Jabon, buffalo and livestock, and cultivation efforts carried out by the company.

The value of land used as productive land to be used as agroforestry land has a higher economic valuation value with the time of planting for eight years will get an income of Rp. 664.604.647.00/year and not only used for revegetation purposes. Likewise, the results of the business feasibility were based on an area of 15.421 ha with the development of Jabon-type woody plants, aquaculture with tilapia, and livestock by developing Bali cattle and cultivating eucalyptus with the yield of Rp. 4.984.962.000.00 shows that agroforestry business can be carried out and is expected to fulfill the function of land benefits for the community, environment, social and economy. 


\section{Acknowledgments}

This work is supported by Hibah PITTA 2018 funded by DRPM Universitas Indonesia No.2580/UN2.R3.1/HKP.05.00/2018.

\section{References}

1. Ruhimat IS.. Journal of social research and forestry economi (2015)

2. Arifin HS, Wulandari C, Qodarian P, Kaswanto RL. (2009)

3. Kodir, A. Thesis. Universitas Indonesia. (2016)

4. Widiyanto, A \& Siarudin, M. Journal of forest products research (2013)

5. Setiyono,S, Kusuma, Andri Haryono Awalokta, Rusman. Veteriner journal (2017) 